\title{
PENGGUNAAN ENRICHMENT-SELECTIVE MEDIUM UNTUK MENINGKATKAN SENSITIVITAS PEMERIKSAAN LABORATORIUM DIFTERI
}

\section{THE USE OF ENRICHMENT-SELECTIVE MEDIUM TO IMPROVE SENSITIVITY IN DIPHTERIA EXAMINATION IN THE LABORATORY}

\author{
Sunarno $^{1 *}$, Novi Amalia ${ }^{1}$, Sundari Nursofiah ${ }^{1}$, Tati Febrianti ${ }^{1}$ \\ ${ }^{1}$ Pusat Penelitian dan Pengembangan Biomedis dan Teknologi Dasar Kesehatan, J1. Percetakan Negara 23 \\ Jakarta Pusat 10560 \\ *email: no_nar@yahoo.com
}

\begin{abstract}
ABSTRAK
Konfirmasi laboratorium kasus difteri dilakukan dengan isolasi dan tes toksigenisitas bakteri penyebab difteri menggunakan metode konvensional berbasis kultur. Metode konvensional memiliki keterbatasan dalam hal sensitivitas pemeriksaan. Penelitian ini bertujuan untuk menguji penggunaan darah domba + telurit sebagai enrichment-selective medium untuk meningkatkan sensitivitas pemeriksaan laboratorium difteri dengan metode konvensional. Sebanyak 18 spesimen klinis (swab tenggorok) penderita difteri digunakan sebagai sampel penelitian. Swab tenggorok tersebut sebelumnya telah digunakan untuk pemeriksaan Polymerase Chain Reaction (PCR) sehingga proses ekstraksi DNA menyebabkan jumlah sel bakteri yang tertinggal menjadi sangat terbatas. Sel bakteri tersebut ditumbuhkan menggunakan 2 cara yang berbeda, yaitu inokulasi langsung dan inokulasi yang didahului dengan penggunaan enrichment-selective medium. Hasil identifikasi bakteri penyebab difteri dibandingkan antara keduanya. Hasil penelitian menunjukkan bahwa inokulasi secara langsung hanya berhasil mengisolasi dan mengidentifikasi bakteri penyebab difteri (Corynebacterium diphtheriae) pada 3 dari 18 sampel yang diperiksa. Sebaliknya dengan penggunaan enrichment-selective medium, bakteri penyebab difteri berhasil diisolasi dan diidentifikasi pada 9 dari 18 sampel yang diperiksa. Oleh karena itu, disimpulkan bahwa enrichment-selective medium (darah domba + telurit) dapat digunakan untuk meningkatkan sensitivitas pemeriksaan laboratorium difteri.
\end{abstract}

Kata kunci: Difteri, Enrichment-Selective Medium, Laboratorium, Sensitivitas.

\begin{abstract}
Laboratory confirmation for diphtheria cases are performed by using conventional culture-based method for isolation/identification and toxigenicity of the bacteria causing diphtheria. This method has limitation in its sensitivity. This study aimed to examine the sensitivity of sheep blood + tellurite as the enrichment selective medium to improve the sensitivity of the conventional method. The samples were 18 clinical specimens (throat swabs) obtained from diphtheria patient, which had been used for Polymerase Chain Reaction (PCR) assay, therefore the DNA extraction process caused the number of bacteria cells to be very limited. The samples were cultured by two different methods, directly on the agar medium and indirectly through enrichment selective medium previously. The result showed that the directly inoculation could isolate C. diphtheriae as many as 3 out of 18 samples, whereas indirectly method by using enrichment selective medium could isolate and identify 9 out of 18 samples. In conclusion, enrichment
\end{abstract}


selective medium (sheep blood + tellurite) may improve the examination sensitivity of bacteria causing diphtheria identification in the laboratory.

Keywords: Diphtheria, Enrichment-Selective Medium, Laboratory, Sensitivity.

\section{PENDAHULUAN}

Difteri masih menjadi masalah kesehatan, khususnya di negara-negara berkembang dengan cakupan imunisasi yang relatif masih rendah, ${ }^{1}$ termasuk Indonesia. Data World Health Organization (WHO) dan Kementerian Kesehatan RI menunjukkkan bahwa Indonesia menempati peringkat ke-3 sampai dengan ke-2 negara dengan kasus difteri terbanyak di dunia dalam 5 tahun terakhir. Tahun 2013, Indonesia menempati peringkat ke-2 setelah India dengan jumlah kasus 775. Tahun 2014, Indonesia menempati peringkat ke-3 dengan jumlah kasus 430 setelah terjadi peningkatan kasus di Nepal. Tahun 2015 dan 2016, Indonesia kembali menduduki peringkat ke-3 dengan 492 kasus setelah terjadi peningkatan kasus di Madagascar dan penurunan kasus di Nepal. Tahun 2017, Indonesia kembali menduduki peringkat ke2 setelah India dengan 954 kasus, meskipun kasus di Nepal juga meningkat dan tidak ada laporan dari Madagascar. Sejauh ini, India selalu menempati peringkat pertama negara dengan kasus difteri terbanyak di dunia selama 10 tahun terakhir. ${ }^{2-4}$

Diagnosis klinis difteri ditegakkan berdasarkan gambaran klinis pasien, seperti demam dan sakit tenggorok yang ikut disertai dengan terbentuknya pseudo membran. ${ }^{5-7}$ Diagnosis laboratorium digunakan untuk konfirmasi kasus klinis, termasuk tes toksigenisitas bakteri penyebab difteri. ${ }^{2,8}$ Dalam hal ini, pemeriksaan laboratorium untuk konfirmasi difteri adalah dengan metode konvensional berbasis kultur. Selain lamanya waktu pemeriksaan, ${ }^{9}$ keterbatasan lain dalam pemeriksaan laboratroium difteri dengan metode konvensional adalah rendahnya positive rate. ${ }^{10,11}$ Positive rate yang rendah umumnya disebabkan karena kekurangtajaman dalam menegakkan diagnosis klinis, namun sensitivitas metode pemeriksaan laboratorium juga berpengaruh. Sensitivitas pemeriksaan laboratorium dapat ditingkatkan dengan metode PCR, namun hingga saat ini pemeriksaan PCR belum bisa diterima sebagai metode untuk konfirmasi laboratorium kasus difteri. ${ }^{12,13}$

Salah satu upaya untuk meningkatkan sensitivitas pemeriksaan laboratorium menggunakan metode konvensional (kultur) dapat dilakukan dengan menumbuhkan bakteri pada medium pengayaan (enrichment). Enrichment-selective medium merupakan medium pengayaan yang ditambah dengan agen selektif untuk menghambat pertumbuhan bakteri non target sekaligus 
membantu pertumbuhan dan meningkatkan jumlah bakteri target pada sampel. ${ }^{14,15}$ Penelitian ini bertujuan untuk menganalisis manfaat penggunaan enrichment-selective medium (darah domba + telurit) terhadap peningkatan sensitivitas pemeriksaan difteri. Darah domba digunakan sebagai sumber nutrisi bakteri penyebab difteri sehingga dapat tumbuh dengan baik, sedangkan telurit digunakan untuk menekan pertumbuhan bakteri lain yang dapat mengganggu pertumbuhan bakteri penyebab difteri Penelitian ini merupakan studi pendahuluan dengan jumlah sampel terbatas.

\section{METODE}

Sampel terdiri dari 18 spesimen klinis (usap tenggorok) penderita difteri yang telah selesai diidentifikasi dalam pemeriksaan laboratorium difteri dengan metode konvensional dan PCR. Jumlah sel bakteri yang tertinggal pada spesimen klinis diperkirakan sangat terbatas mengingat bahwa pada sampel tersebut telah dilakukan ekstraksi DNA, untuk itu sel bakteri yang ada pada sampel "dirontokkan" dengan menggunakan mesin vorteks. ${ }^{16}$ Sampel tersebut digunakan sebagai model yang menyerupai sampel klinis baru dari penderita difteri maupun kontak erat penderita dengan jumlah sel bakteri target terbatas. Semua sampel diperiksa dengan 2 prosedur pemeriksaan, langsung (tanpa enrichment-selective medium) dan dengan enrichment-selective medium secara berurutan. Penelitian dilakukan di Laboratorium Bakteriologi, Laboratorium Penelitian Penyakit Infeksi Dr. Sri Oemijati, Puslitbang Biomedis dan Teknologi Dasar Kesehatan. Persetujuan etik diperoleh dari Komisi Etik Badan Penelitian dan Pengembangan Kesehatan No.: LB.02.01/2/KE216/2017 tahun 2017.

Sebanyak 2,5 $\mathrm{ml}$ defibrinated sheep blood dimasukkan ke dalam tabung gelas steril bertutup ulir. Sebanyak 25 ul larutan telurit $3 \%$ ditambahkan ke dalamnya sehingga konsentrasi final telurit dalam medium adalah $0,03 \%$. Hal ini mengacu pada konsentrasi final telurit pada medium yang umum digunakan dalam pemeriksaan difteri. ${ }^{17}$ Larutan telurit diratakan dengan cara menggoyang tabung secara perlahan dan enrichment-selective medium siap digunakan.

Metode pertama dilakukan tanpa penggunaan enrichment-selective medium. Sampel (usap tenggorok) di-streak secara langsung pada medium selektif untuk pemeriksaan difteri, yaitu Cystine Tellurite Blood Agar (CTBA). Inkubasi dilakukan pada suhu $37^{\circ} \mathrm{C}$ selama 48 jam. Hasil pertumbuhan koloni diidentifikasi secara mikroskopik dan dilanjutkan dengan tes biokimia standar untuk pemeriksaan laboratorium difteri sesuai dengan pedoman WHO. ${ }^{18}$ Setelah di-streak secara langsung pada medium CTBA, sampel diperiksa 


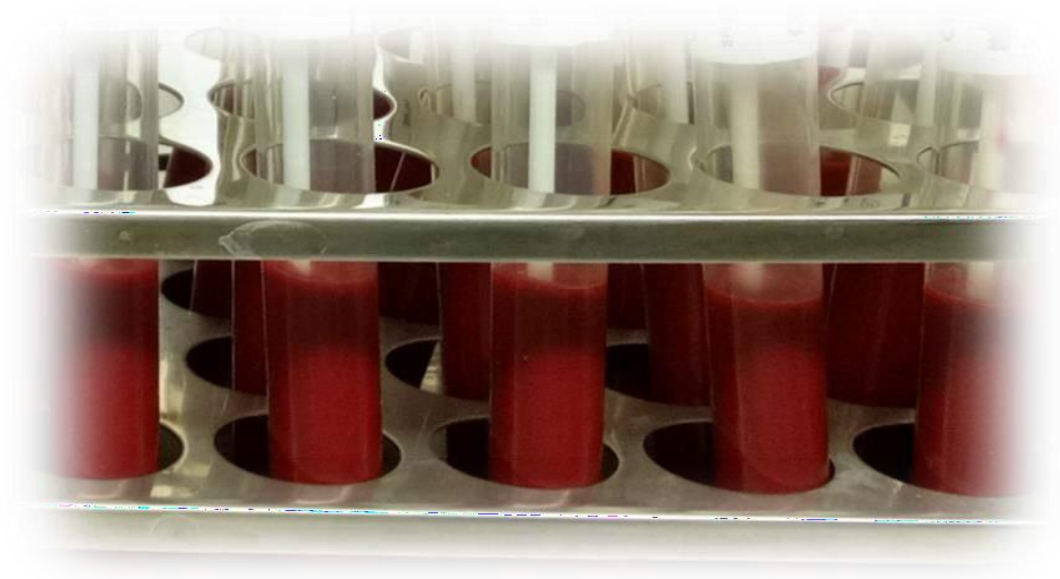

Gambar 1. Enrichment-selective medium

dengan metode kedua (penggunaan Selanjutnya sampel tersebut diperiksa enrichment-selective medium). Sampel dengan cara yang sama sesuai langkahdimasukkan terlebih dahulu ke dalam langkah pada metode pertama. Hasil tabung yang berisi sekitar 2,5 ml identifikasi sampel dibandingkan antara enrichment-selective medium (Gambar 1) metode pertama (langsung) dengan metode dan kemudian diinkubasi pada suhu $37^{\circ} \mathrm{C}$ ke-2 (didahului penggunaan enrichmentselama 24 jam. selective medium).

\section{HASIL}

Tabel 1. Perbandingan hasil pemeriksaan kultur dengan dan tanpa enrichmentselective medium

\begin{tabular}{lcc}
\hline Sampel & Tanpa enrichment-selective medium & Enrichment- selective medium \\
\hline Sampel 1 & Positif & Positif \\
Sampl 2 & Negatif & Positif \\
Sampel 3 & Positif & Positif \\
Sampel 4 & Negatif & Positif \\
Sampel 5 & Negatif & Negatif \\
Sampel 6 & Negatif & Positif \\
Sampel 7 & Negatif & Positif \\
Sampel 8 & Negatif & Negatif \\
Sampel 9 & Negatif & Negatif \\
Sampel 10 & Negatif & Negatif \\
Sampel 11 & Negatif & Negatif \\
Sampel 12 & Negatif & Positif \\
Sampel 13 & Negatif & Negatif \\
Sampel 14 & Negatif & Negatif \\
Sampel 15 & Negatif & Negatif \\
Sampel 16 & Negatif & Negatif \\
Sampel 17 & Positif & Positif \\
Sampel 18 & Negatif & Positif \\
\hline Total positif & $\mathbf{3}$ & $\mathbf{9}$ \\
\hline
\end{tabular}


Tabel 1 mengindikasikan bahwa penggunaan enrichment-selective medium dapat meningkatkan sensitivitas pemeriksaan laboratorium bakteri penyebab difteri hingga 3 kali lipat pada kondisi jumlah sel bakteri yang terdapat pada sampel terbatas (sedikit).

Perbandingan hasil pemeriksaan antara metode pertama (langsung) dengan metode ke- 2 (didahului penggunaan enrichment-selective medium) dapat dilihat pada Tabel 1 .

\section{PEMBAHASAN}

Pemeriksaan laboratorium difteri penting dilakukan untuk konfirmasi kasus dan deteksi adanya penularan penyakit dari atau kepada kontak erat penderita. ${ }^{2,19}$ Hasil pemeriksaan laboratorium dengan metode konvensional berbasis kultur ditentukan oleh keberhasilan me-recovery bakteri target yang terdapat pada sampel klinis. Dalam hal ini, dibutuhkan sel bakteri hidup dengan jumlah cukup banyak untuk bisa ditumbuhkan dengan medium kultur. Di sisi lain, seringkali sulit mendapatkan jumlah sel bakteri hidup yang cukup banyak saat pengambilan sampel. Terlebih lagi pada kondisi dimana pasien telah mendapatkan terapi antibiotik sebelumnya. Ini perlu menjadi catatan mengingat pada pemeriksaan kultur difteri, medium yang digunakan untuk kultur primer (inokulasi sampel klinis) adalah medium selektif yang umumnya mengandung telurit. Selain menekan pertumbuhan bakteri nontarget, telurit dapat sedikit menekan pertumbuhan bakteri target pada medium kultur, ${ }^{20}$ meskipun secara alami bakteri penyebab difteri memiliki faktor resistensi terhadap telurit. ${ }^{21}$ Hal ini akan menjadi masalah jika jumlah sel bakteri target pada sampel terbatas.

Pada penelitian ini enrichmentselective medium digunakan untuk membantu recovery bakteri penyebab difteri pada medium kultur dengan memfasilitasi pertumbuhan bakteri target dan menekan pertumbuhan bakteri nontarget. Enrichment-selective medium yang digunakan cukup sederhana, yaitu dengan menambahkan telurit $0,03 \%$ ke dalam darah domba. Darah domba merupakan sumber nutrisi yang cocok dan paling sering digunakan untuk menumbuhkan bakteri penyebab difteri pada medium kultur. Di sisi lain, telurit merupakan agen selektif yang sangat baik untuk menekan pertumbuhan bakteri non target sehingga tidak mengganggu pertumbuhan bakteri penyebab difteri sebagai target pemeriksaan. ${ }^{17}$

Penggunaan enrichment maupun enrichment-selective medium untuk meningkatkan sensitivitas pemeriksaan mikroorganisme telah dilakukan dalam beberapa penelitian sebelumnya. Moran, et al. menggunakan Bolton broth dalam 
isolasi Campylobacter spp. ${ }^{22}$ Hyeon, et al. mengevaluasi efektivitas penggunaan 2 jenis selective enrichment broth (Rappaport-Vassiliadis Soya Peptone / RVS dan Muller-Kauffmann Tetrathionate-Novobiocin / MKTTn) dalam isolasi Salmonella dari ayam. ${ }^{23}$ Sementara itu, Yu, et al. menggunakan selective enrichment broth (SSL) untuk meningkatkan pertumbuhan beberapa jenis bakteri secara bersamaan, meliputi Salmonella enterica serovar Enteritidis, Staphylococcus aureus, dan Listeria monocytogenes. $^{24} \quad$ Pengembangan enrichment broth berupa fastidious broth (FB) juga pernah dilakukan sebelumnya untuk kultivasi mikroorganisme fastidious seperti Corynebacterium jeikeium (satu genus dengan bakteri penyebab difteri) oleh Cartwright, et al. ${ }^{25}$

Hasil penelitian ini menunjukkan bukti awal bahwa penggunaan enrichmentselective medium darah domba yang disuplementasi dengan telurit dapat digunakan untuk meningkatkan sensitivitas pemeriksaan laboratorium difteri menggunakan metode konvensional berbasis kultur. Namun demikian, perlu diingat bahwa penggunaan medium ini memiliki konsekuensi terhadap peningkatan biaya dan penambahan waktu pemeriksaan. Hal lain yang perlu digarisbawahi bahwa enrichment-selective medium darah domba yang disuplementasi dengan telurit tidak dapat disimpan dalam waktu lama karena berbahan dasar meterial biologi. Medium ini hanya bisa disimpan pada suhu 2-8 ${ }^{\circ} \mathrm{C}$ (bukan freezer) dan baik digunakan dalam 1 minggu setelah pembuatan. Dalam hal ini, penggunaan dalam kondisi fresh (segera setelah pembuatan) sangat dianjurkan.

\section{KESIMPULAN}

Penggunaan enrichment-selective medium darah domba yang disuplementasi dengan telurit dapat meningkatkan sensitivitas pemeriksaan laboratorium difteri menggunakan metode konvensional.

\section{SARAN}

Penelitian ini merupakan pilot project dengan melibatkan jumlah sampel yang terbatas. Penelitian lebih lanjut dengan melibatkan sampel yang lebih banyak disarankan untuk memperkuat kesimpulan.

\section{KONTRIBUSI PENULIS}

Kontribusi penulis pada artikel ini yaitu, S sebagai kontributor utama berkontribusi jawab dalam seluruh proses penelitian hingga publikasi. Kontributor anggota yaitu NA dan SF berkontribusi dalam dalam pemeriksaan laboratorium difteri, serta TF berkontribusi dalam dalam pembuatan dan finalisasi naskah publikasi. 


\section{UCAPAN TERIMA KASIH}

Ucapan terima kasih kami sampaikan kepada seluruh pihak yang berperan dalam penelitian ini, khususnya Rita Marleta Dewi, Sauma R Intan, dan Aulia Rizky. Ucapan terima kasih juga kami sampaikan kepada pimpinan dan staf administrasi yang telah membantu pendanaan penelitian.

\section{DAFTAR PUSTAKA}

1. Dandinarasaiah M, Vikram BK, Krishnamurthy N, Chetan AC, Jain A. Diphtheria Re-emergence: Problems Faced by Developing Countries. Indian $J$ Otolaryngol Head Neck Surg. 2013;65(4):314-318. doi:10.1007/s12070-012-0518-5

2. Mathur SB, Mukherjee SB. Diphteria Revisited. Indian Pediatr. Published online 2017:411-412. https://indianpediatrics.net/oct2018/oct -903-904.htm

3. World Health Organization. Diphteria Reported Cases. Published online 2019. http://www.who.int/immunization/mon itoring_surveillance/routine/reporting/e $\mathrm{n} /$

4. Directorate General of Disease and Prevention Control Ministry of Health RI. Integrated Surveillance for Disease that Can $\mathrm{Be}$ Prevented by Immunization. Published online 2014:2014.

5. Loganathan T, Bin Yusof MP. Adult Diphtheria in Malaysia: A Case Report. Med J Malaysia. 2018;73(5):340-341.

6. Puspitasari D, Ernawati, Husada D. Gambaran Klinis Penderita Difteri Anak di RSUD Dr . Soetomo (Clinical Features of Children with Diphtheria on Soetomo Hospital). 2012;(2):2012.

7. Pancharoen C, Mekmullica J, Thisyakorn U, Nimmannitya S. Clinical Features of Diphtheria in Thai
Children: A Historic Perspective. Southeast Asian J Trop Med Public Health. 2002;33(2):352-354.

8. Udgaonkar U. Carrier Study and Treatment of Close Contacts : A Must for Diphteria Eradication. Indian J Med Microbiol. doi:10.4103/ijmm.IJMM

9. Sunarno, Kambang Sariadji, Holly Arif Wibowo. Potensi Gen dtx dan dtxR sebagai Marker untuk Deteksi dan Pemeriksaan Toksigenitas Corynebacterium diphtheriae. Bul Penelit Kesehat. 2013;41(1):1-10.

10. Bhagat S, Grover SS, Gupta N, Roy RD, Khare S. Persistence of Corynebacterium diphtheriae in Delhi \& National Capital Region (NCR). Indian $J$ Med Res. 2015;142(OCTOBER):459-461. doi:10.4103/0971-5916.169212

11. Meera M, Rajarao M. Diphtheria in Andhra Pradesh-A ClinicalEpidemiological Study. Int J Infect Dis. 2014;19(1):74-78. doi:10.1016/j.ijid.2013.10.017

12. Nakao H, Popovic T. Development of a Direct PCR Assay for Detection of the Diphtheria Toxin Gene. $J$ Clin Microbiol. 1997;35(7):1651-1655. doi:10.1128/jcm.35.7.1651-1655.1997

13. World Health Organization. Vaccine Preventable Disease Surveillance Standards. Published 2018. https://www.who.int/immunization/mo nitoring_surveillance/burden/vpd/stand ards/en/

14. Rouf A, Kanojia V, Naik H, Naseer B, Qadri T. An Overview of Microbial Cell Culture. J Pharmacogn Phytochem. 2017;6(6):1923-1928.

15. Kaur R, Wischmeyer J, Morris M, Pichichero ME. Comparison of DirectPlating and Broth-Enrichment Culture Methods for Detection of Potential Bacterial Pathogens in Respiratory Secretions. J Med Microbiol. 2017;66(11):1539-1544. doi:10.1099/jmm.0.000587 
16. Cho MC, Kim H, An D, et al. Comparison of Sputum and Nasopharyngeal Swab Specimens for Molecular Diagnosis of Mycoplasma pneumoniae, Chlamydophila pneumoniae, and Legionella pneumophila. Ann Lab Med. 2012;32(2):133-138. doi:10.3343/alm.2012.32.2.133

17. Sariadji K, Sunarno S, Khariri K, Puspandari N, Muna F, Rukminiati Y. Selektivitas Medium Cystine Tellurite Blood Agar (CTBA) terhadap Beberapa Isolat Bakteri. J Kefarmasian Indones. 2015;5(1):19-24. doi:10.22435/jki.v5i1.4082.19-24

18. Efstratiou A, Maple C. Manual for the Laboratory Diagnosis of Diphteria. Eur Reg World Heal Organ. 1994;47(1):3341.

19. Jané M, Vidal MJ, Camps N, et al. A Case of Respiratory Toxigenic Diphtheria: Contact Tracing Results and Considerations Following A 30Year Disease-Free Interval, Catalonia, Spain, 2015. Eurosurveillance. 2018;23(13):1-6. doi:10.2807/15607917.ES.2018.23.13.17-00183

20. Sunarno, Sariadji K. Teknik Penyimpanan dan Prospek Transportasi Isolat Corynebacterium diphteriae Menggunakan Silica Gel. Biotek Medisiana Indones. 2017;6(2).

21. dos Santos LS, Antunes CA, dos Santos CS, et al. Corynebacterium diphtheriae Putative Tellurite-
Resistance Protein (CDCE8392_0813) Contributes to The Intracellular Survival in Human Epithelial Cells and Lethality of Caenorhabditis elegans. Mem Inst Oswaldo Cruz. 2015;110(5):662-668. doi:10.1590/0074-02760140479

22. Moran L, Kelly C, Cormican M, Mcgettrick S, Madden RH. Restoring the Selectivity of Bolton Broth During Enrichment for Campylobacter spp. From Raw Chicken. Lett Appl Microbiol. 2011;52(6):614-618. doi:10.1111/j.1472-765X.2011.03046.x

23. Hyeon JY, Park JH, Chon JW, et al. Evaluation of Selective Enrichment Broths and Chromogenic Media for Salmonella Detection in Highly Contaminated Chicken Carcasses. Poult Sci. 2012;91(5):1222-1226. doi:10.3382/ps.2011-01936

24. Yu YG, Wu H, Liu YY, Li SL, Yang XQ, Xiao XL. A Multipathogen Selective Enrichment Broth for Simultaneous Growth of Salmonella enterica serovar Enteritidis, Staphylococcus aureus, and Listeria monocytogenes. Can J Microbiol. 2010;56(7):585-597. doi:10.1139/W10040

25. Cartwright CP, Stock F, Gill VJ. Improved Enrichment Broth for Cultivation of Fastidious Organisms. $J$ Clin Microbiol. 1994;32(7):1825-1826. doi:10.1128/jcm.32.7.1825-1826.1994 